\title{
Relationship between Site-Specific HSL Phosphorylation and Adipocyte Lipolysis in Obese Women
}

\author{
Silvia Lorente-Cebrián ${ }^{\mathrm{a}} \quad$ Agné Kulyté $^{\mathrm{a}} \quad$ Per Hedén $^{\mathrm{b}} \quad$ Erik Näslund $^{\mathrm{c}} \quad$ Peter Arner $^{\mathrm{a}}$ \\ Mikael Rydén ${ }^{\mathrm{a}}$ \\ a Department of Medicine Huddinge, Lipid Laboratory, Karolinska Institutet, NVS, Karolinska University Hospital, \\ ${ }^{\mathrm{b}}$ Department of Plastic Surgery Akademikliniken, \\ ${ }^{\circ}$ Department of Clinical Sciences, Danderyd Hospital, Karolinska Institutet, Stockholm, Sweden
}

Keywords

Adipocyte · Lipolysis · Obesity

\section{Summary}

Background/Aims: In fat cells of obese humans, basal lipolysis is increased but catecholamine-stimulated lipolysis is blunted. This is linked to decreased expression of hormone-sensitive lipase (HSL). Upon stimulation by CAMP, HSL is phosphorylated at several serine residues (P-Ser ${ }^{552}, \mathrm{P}-\mathrm{Ser}^{649}$ and P-Ser ${ }^{650}$ ) leading to enzymatic activation. In contrast, P-Ser ${ }^{554}$ prevents phosphorylation at $\mathrm{Ser}^{552}$ and is thus considered an inactivating site. We hypothesized that differences in HSL phosphorylation could be linked to disturbed adipocyte lipolysis in obesity. Methods: Phosphorylation at Ser ${ }^{552}, \mathrm{Ser}^{554}, \mathrm{Ser}^{650}$ as well as total HSL and adipose triglyceride lipase (ATGL) protein expression were assessed by Western blot in subcutaneous adipose tissue samples of 32 obese women. Basal and stimulated lipolysis in isolated fat cells were correlated to phosphorylation levels. Results: While there was no correlation between basal lipolysis and P-Ser 650 or P-Ser ${ }^{554}$, there was a negative correlation with P-Ser ${ }^{552}$ $(r=0.39 ; p<0.05)$. In contrast, only P-Ser ${ }^{554}$ was strongly and negatively correlated with noradrenaline- $(r=-0.50$; $p<0.01)$ and dibutyryl cAMP-stimulated $(r=-0.45 ; p<0.05)$ lipolysis. There were no significant correlations between any measure of lipolysis and total levels of HSL and ATGL. Conclusion: In contrast to total HSL and ATGL levels, phosphorylation at $\operatorname{Ser}^{554}$ and $\operatorname{Ser}^{552}$, but not at Ser ${ }^{650}$, may differentially predict adipocyte lipolysis in vitro. Posttranslational modifications of HSL may therefore constitute an important regulator of adipocyte lipolysis, at least in adipose tissue of obese women. Whether this is also relevant in lean individuals remains to be demonstrated.

\section{Introduction}

Obesity is a major public health problem which is closely associated with the development of insulin resistance. One important etiological factor for obesity-associated insulin resistance is increased release of free fatty acids (FAs) from adipose tissue [1] due to dysregulated lipolysis [2, 3].

It has been conclusively shown that the unstimulated (basal) rate of lipolysis is increased [4], whereas catecholamine-stimulated lipolysis is attenuated in obese subjects $[5,6]$. In humans, unlike rodents, basal lipolysis is marked and the elevated rate in obesity may, at least in part, account for the increase in circulating FAs in this condition [7]. However, the pathogenic factors behind this altered lipolytic response in obesity are not completely understood [reviewed in 8].

In mammals, stored triglycerides are hydrolyzed into glycerol and FAs in a three-step process catalyzed by the consecutive action of adipose triglyceride lipase (ATGL), hormonesensitive lipase (HSL), and monoglyceride lipase. Regulation of human fat cell lipolysis is subject to tight hormonal control; in humans, the main regulators are catecholamines and natriuretic peptides (pro-lipolytic) and insulin (anti-lipolytic) [reviewed in 8,9$]$. Catecholamines stimulate lipolysis through $\beta$-adrenoreceptors which via Gs-proteins activate adenylate cyclase leading to an increase in the intracellular levels of cAMP. Activation of protein kinase A (PKA) by cAMP leads to phosphorylation of a lipid droplet coating protein termed perilipin which then releases CGI-58, a regulating factor that binds and activates ATGL. ATGL and CGI-58 form a complex that catalyzes the initial steps of lipolysis at the surface of the lipid droplet. PKA also phosphorylates and activates HSL which then translocates from the cytoplasm to the lipid droplet, associates with perilipin and continues the hydrolysis of primarily diglycerides. Lipolysis is attenuated by reducing the

\section{KARGER}

Fax +497614520714

Information@Karger.de

www.karger.com
(C) 2011 S. Karger GmbH, Freiburg

$1662-4025 / 11 / 0045-0365 \$ 38.00 / 0$

Accessible online at:

www.karger.com/ofa
Silvia Lorente-Cebrián, $\mathrm{PhD}$

Department of Medicine Huddinge, Lipid Laboratory,

Karolinska Institutet, NVS, Karolinska University Hospital

14186 Stockholm, Sweden

Tel. +46 8 5858-0623, Fax -5470

Silvia.Lorente-Cebrian@ki.se 
intracellular levels of cAMP. This can be achieved via different mechanisms: activation of Gi-coupled receptors (e.g $\alpha_{2 \mathrm{~A}^{-}}$ adrenoceptors and adenosine receptors) reduces the activity of adenylate cyclase while insulin inhibits lipolysis via the enzyme phosphodiesterase-3B which converts cAMP into 5'-AMP.

The role of ATGL in the pathophysiology of obesity is unclear $[10,11]$, and very little is known about ATGL levels in adipose tissue and the regulation of human adipocyte lipolysis. In contrast, HSL expression and activity correlate positively with hormone-stimulated lipolysis in human fat cells. Several studies suggest that differences in HSL protein expression could be involved in the development and progress of both obesity [5, 12] and cancer cachexia [13]. Numerous studies have shown that HSL expression and activity are decreased in obese subjects $[5,11,12]$ and increased in subcutaneous fat of patients with cancer cachexia [13]. HSL activity could therefore be important in determining lipid turnover which is reduced in obesity but increased in cachexia.

While ATGL activity seems to be highly dependent on the association with CGI-58 [14], HSL activity is post-translationally regulated by phosphorylation at multiple serine residues which are highly conserved in rat and human HSL: in humans, $\mathrm{Ser}^{552}, \mathrm{Ser}^{649}$, and $\mathrm{Ser}^{650}$ (corresponding to rat $\mathrm{Ser}^{563}, \mathrm{Ser}^{659}$ and $\mathrm{Ser}^{660}$ ) are considered to be the major phosphorylation sites for PKA [reviewed in 9] although the relevance of phosphorylation at $\operatorname{Ser}^{552}$ has been somewhat unclear $[15,16]$. Moreover, while not regulated by PKA, an additional phosphorylation site at $\mathrm{Ser}^{589}$ (corresponding to rat $\mathrm{Ser}^{600}$ ) has been demonstrated to be activated by MAPKs/ERKs (mitogenactivated protein kinases / extracellular (signal-)regulated kinases) [17].

Conversely, following a decrease in cAMP concentrations, HSL activity is negatively regulated by AMP kinase (AMPK) through phosphorylation at $\operatorname{Ser}^{554}$ (corresponding to rat Ser ${ }^{565}$ ) [18]. Phosphorylation at this site prevents HSL phosphorylation by PKA and is thus considered an inactivating residue [18-20] although controversial findings regarding the role of this phosphorylation site have also been reported [21, 22].

Recent studies using site-directed mutagenesis have confirmed that P-Ser ${ }^{649}$ and P-Ser ${ }^{650}$ are major PKA phosphorylation sites which determine lipolytic activity in humans [23]. In addition, Watt et al. [24] showed in vivo that phosphorylation at $\mathrm{Ser}^{650}$ in human adipose tissue could overcome the inactivating effect of AMPK-induced $\mathrm{P}-\mathrm{Ser}^{554}$ during bouts of prolonged exercise. To our knowledge, there are no reports regarding the correlation between HSL phosphorylation levels in human adipocytes/adipose tissue and different measures of lipolysis. We hypothesized that alterations in HSL phosphorylation could be linked to measures of adipocyte lipolysis in the obese state. We therefore investigated whether HSL phosphorylation levels at $\mathrm{Ser}^{552}, \mathrm{Ser}^{554}$, and $\mathrm{Ser}^{650}$ could predict adipocyte lipolysis in vitro in obese women. As a comparison, we also determined the total levels of HSL and ATGL in the same samples.
Table 1. Clinical characteristics of the subjects included in the study. Values are mean $\pm \mathrm{SD}(\mathrm{n}=34)$

\begin{tabular}{ll}
\hline Age & $39.4 \pm 7.9$ years \\
BMI & $43.2 \pm 5.8 \mathrm{~kg} / \mathrm{m}^{2}$ \\
Waist/hip & $0,996 \pm 0.068$ \\
Fasting glucose & $5.2 \pm 0.5 \mathrm{mmol} / 1$ \\
Insulin & $17.1 \pm 9.1 \mu \mathrm{U} / \mathrm{ml}$ \\
HOMA index & $3.7 \pm 1.7 \mathrm{RU}$ \\
Total cholesterol & $4.8 \pm 0.8 \mathrm{mmol} / 1$ \\
Triglycerides & $1.5 \pm 0.6 \mathrm{mmol} / 1$ \\
HDL cholesterol & $1.1 \pm 0.2 \mathrm{mmol} / 1$ \\
Smoking, n $(\%)$ & $9(26.5 \%)$ \\
\hline
\end{tabular}

\section{Participants and Methods}

\section{Subjects}

34 premenopausal nondiabetic obese women (age $39.4 \pm 7.9$ years, BMI $43.2 \pm 5.8 \mathrm{~kg} / \mathrm{m}^{2}$ ) were enrolled in the present study. Clinical data are summarized in table 1 . Five subjects had hypertension, but none were on treatment with $\beta$-blockers. Nine of the participants were smokers by the time they were included in the study. Subjects were explained in detail about procedures and associated risks and written informed consent was obtained. This study was conducted in accordance with the guidelines in the Declaration of Helsinki and approved by the Regional Ethics Board of Stockholm.

After an overnight fast, body fat content was determined by dualenergy X-ray absorptiometry (DEXA). A venous blood sample was obtained for measurement of glucose, insulin, total cholesterol, high-density lipoprotein (HDL) cholesterol, and triglycerides. Insulin and glucose levels were used to calculate insulin sensitivity HOMA index as previously described [25] and revealed that subjects were euglycemic and had no diabetes at the time they were enrolled in the study. Anthropometric measurements (height, weight, and waist/hip circumference) were measured, and a subcutaneous abdominal fat biopsy was obtained as described previously [26]. Needle biopsies of abdominal subcutaneous adipose tissue were also obtained under local anesthesia in the same morning after overnight fast; at least $1 \mathrm{~g}$ of tissue was needed for the experiments.

\section{Lipolysis Experiments}

Adipose tissue samples were cut into small fragments and adipocytes were isolated by digestion with collagenase as described previously [12]. Fat-cell size and number of cells were measured and diluted cell suspensions were incubated in an albumin-containing buffer ( $\mathrm{pH}$ 7.4) supplemented with glucose $(1 \mathrm{~g} / \mathrm{l})$ and ascorbic acid $(0.1 \mathrm{~g} / \mathrm{l})$ for $2 \mathrm{~h}$ at $37^{\circ} \mathrm{C}$ with air gas phase. Adipocytes were incubated in the presence or absence of increasing concentrations of the natural catecholamine noradrenaline (NA) or the phosphodiesterase-resistant cAMP analogue dibutyryl cAMP (dcAMP). Out of the 34 included subjects in this study, isolated fat cells were available from 32 subjects (basal and NA-stimulated lipolysis) or 31 subjects (dcAMP-stimulated lipolysis). After the incubation, an aliquot of the medium was removed to measure glycerol release (as an index of lipolysis). Glycerol release at the maximum effective concentration of lipolysis agent was determined, and its lipolytic effect was calculated as the maximum glycerol release minus the value with no agent present (basal). Glycerol release was expressed per number of incubated fat cells which was calculated as described previously [12].

Western Blot Analysis of Human Adipose Tissue

Adipose tissue samples were frozen in liquid nitrogen and stored at $-80{ }^{\circ} \mathrm{C}$ for further analysis of HSL phosphorylation status. A piece of $300 \mathrm{mg}$ of total adipose tissue was homogenized in buffer containing: $50 \mathrm{mmol} / 1$ Tris- $\mathrm{HCl}$ (pH 7.4), 1\% NP-40, $0.25 \%$ Na-deoxycholate, $150 \mathrm{mmol} / 1 \mathrm{NaCl}, 1 \mathrm{mmol} / \mathrm{l}$ EDTA, $1 \mathrm{mmol} / \mathrm{PMSF}, 3 \mathrm{mg} / \mathrm{ml}$ phosphatase 
inhibitor cocktail, $1 \mathrm{mmol} / 1 \mathrm{Na}_{3} \mathrm{VO}_{4}, 1 \mathrm{mmol} / 1 \mathrm{NaF}$. Homogenates were centrifuged at $12,000 \times g$ for $30 \mathrm{~min}$ at $4{ }^{\circ} \mathrm{C}$. After that, supernatant was removed and protein samples were rapidly frozen. Protein concentration of whole lysates was determined according to the bicinchoninic acid method (Thermo Scientific, Rockford, IL, USA).

Protein lysates from subcutaneous adipose tissue $(100 \mu \mathrm{g})$ were solubilized in Laemmli sample buffer, boiled for $5 \mathrm{~min}$, and resolved by SDSPAGE in $7.5 \%$ polyacrylamide gels. Proteins were then transferred to a nitrocellulose membrane, blocked with 2\% ECL advanced blocking agent (GE Healthcare, Chalfont St. Giles, UK) and immunoblotted with primary antibody. Antibodies directed against specific phosphorylated residues in HSL $\left(\mathrm{Ser}^{52}, \mathrm{Ser}^{554}\right.$, and $\left.\mathrm{Ser}^{650}\right)$ were purchased from Cell Signaling Technology (Beverley, MA, USA). According to the manufacturer and recently published data [27], the antibodies are specific for their cognate phosphorylated residue and do not cross-react with other phosphorylation sites. Anti-p-HSL ( $\mathrm{Ser}^{52}$, $\mathrm{Ser}^{554}, \mathrm{Ser}^{650}$ ), anti-total HSL (Cell Signaling Technology), anti-ATGL (Cell Signaling Technology) were used at 1:1,500 while anti- $\beta$-actin (Sigma-Aldrich, St. Louis, MO, USA) was used

Fig. 1. Phosphorylated HSL and total HSL and ATGL protein expression levels in white adipose tissue of obese women. Equal amounts of total protein were loaded and separated by SDSPAGE. Individual p-HSL and total HSL, ATGL and $\beta$-actin levels were detected by Western blot and

\section{Subject $\mathrm{nr} \quad 1 \quad 2 \quad 3 \quad 4$}

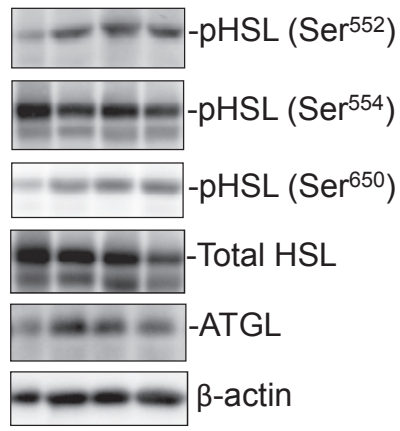

quantified by densitometry as described in material and methods. These representative blots depict the bands detected in four different subjects. at 1:2,000 as described previously [28]. After incubation with primary antibody, membranes were washed and probed with horseradish peroxidase-conjugated secondary antibodies (1:10,000; Sigma-Aldrich). Immunoreactive HSL (phosphorylated or total), ATGL and $\beta$-actin were detected by enhanced chemiluminescence (GE Healthcare) and quantified by densitometry (ChemiDoc XRS; Bio-Rad Laboratories, Gladesville, Australia). Phospho-HSL levels were normalized to total-HSL while total levels of HSL and ATGL were normalized to $\beta$-actin.

\section{Statistical Analysis}

Values are mean \pm SD. Statistical analysis (linear correlation) was performed with standard software packages (Statview 5.01; SAS Institute, Cary, NY, USA).

\section{Results}

\section{P-HSL (Ser $\left.{ }^{552}, \mathrm{Ser}^{554}, \mathrm{Ser}^{650}\right)$, Total HSL, and ATGL Protein Expression Are Detected in Subcutaneous Adipose Tissue of Obese Women}

Bands of $\sim 86 \mathrm{kDa}$ (corresponding to the molecular mass of human HSL), $\sim 56 \mathrm{kDa}$ (ATGL) and $\sim 42 \mathrm{kDa}(\beta$-actin) were detected in all samples using specific antibodies. Representative blots of the immune-reactive bands analyzed in this cohort are depicted in figure 1.

\section{HSL P-Ser ${ }^{552}$ Correlates Negatively with Basal Lipolysis}

HSL phosphorylation at $\mathrm{Ser}^{552}, \mathrm{Ser}^{554}$, and $\mathrm{Ser}^{650}$ was corrected for total HSL protein expression in each sample and compared with basal lipolysis measured in isolated fat cells from the corresponding donor. P-Ser ${ }^{552}$ levels were negatively correlated with basal glycerol release (fig. $2 \mathrm{a}, \mathrm{p}<0.05$ ). In con-
Fig. 2. Correlations between basal lipolysis and phosphorylated/ total HSL levels. Graphs depicting the correlation between basal lipolysis in vitro and $\mathbf{a}$ p-Ser ${ }^{552}, \mathbf{b}$ p-Ser ${ }^{650}$ and $\mathbf{c}$ p-Ser ${ }^{54} \mathrm{HSL}$ as well as $\mathbf{d}$ total protein levels $(\mathrm{n}=32)$. Protein levels were determined by Western blot using antibodies directed against the respective phospho-serine sites or total protein. The quotient between phosphorylated and total HSL levels was used in a-c. Basal lipolysis was assessed in isolated adipocytes by measuring the amount of glycerol released $(\mu \mathrm{mol})$ per $10^{7}$ cells after incubation for $2 \mathrm{~h}$ in an albumincontaining buffer. a
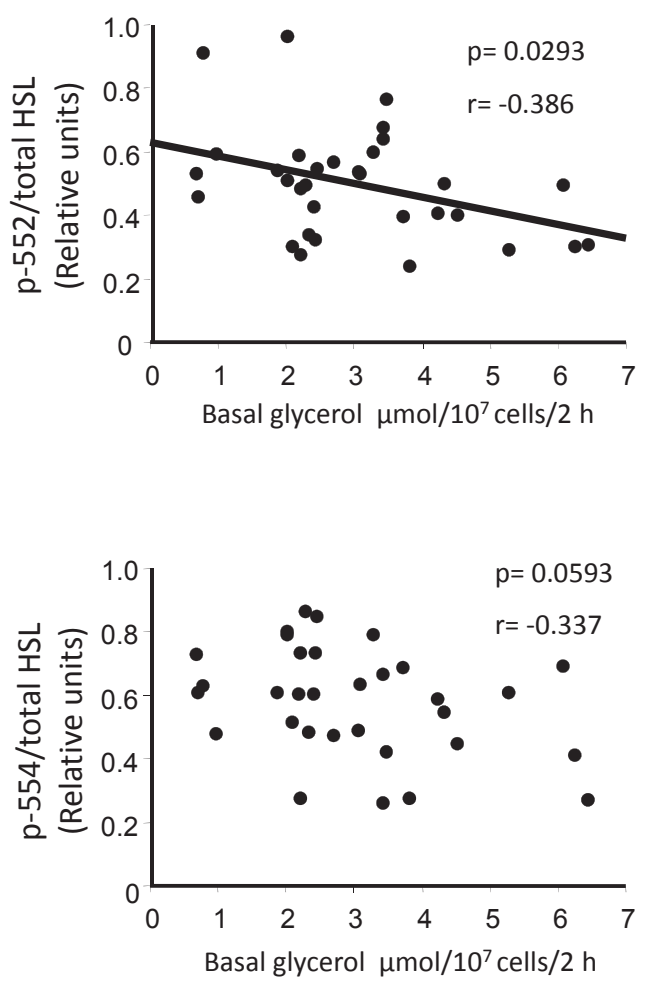

b

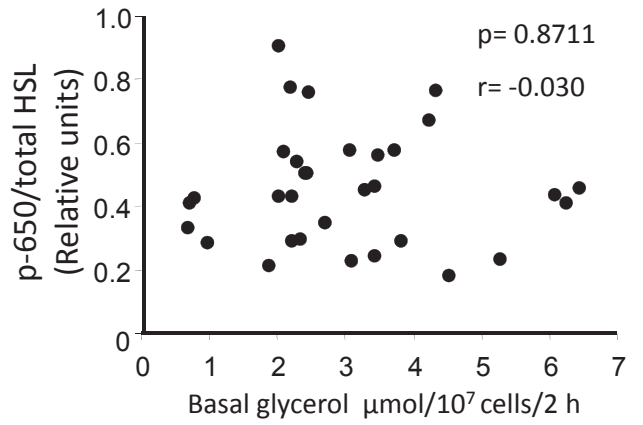

d

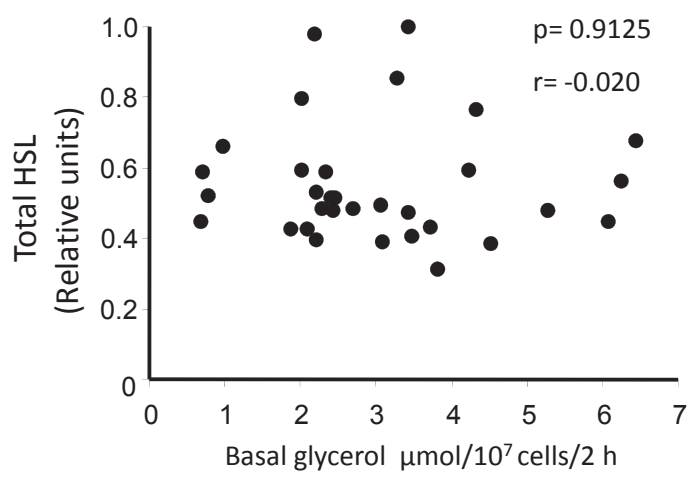


Fig. 3. Correlations between NA-stimulated lipolysis and phosphorylated/total HSL levels. Graphs depicting the correlation between $\mathrm{NA}_{\max }{ }^{-}$ stimulated lipolysis in vitro and $\mathbf{a} \mathrm{p}-\mathrm{Ser}^{552}$, b $\mathrm{p}-\mathrm{Ser}^{650}$ and c $\mathrm{p}-\mathrm{Ser}^{554} \mathrm{HSL}$ as well as d total protein levels $(n=32)$. The quotient between phosphorylated and total HSL levels was used in a-c. Stimulated lipolysis was assessed by measuring the total amount of glycerol released ( $\mu \mathrm{mol})$ per $10^{7}$ cells after incubation with increasing concentrations of $\mathrm{NA}$ for $2 \mathrm{~h}$. ( $\left.\mathrm{NA}_{\max }\right)$ was determined as glycerol released at the maximum effective concentration of NA. Correlations were significant also when subtracting basal lipolysis from the NA-stimulated values.

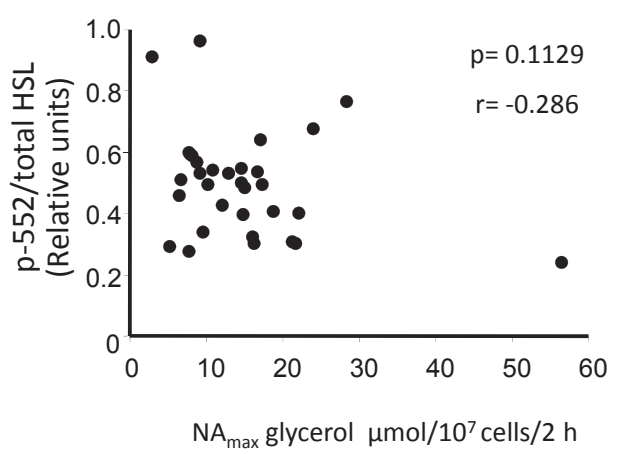

C

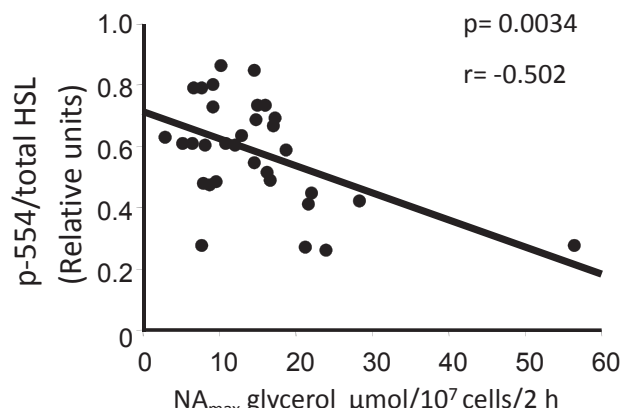

b

d
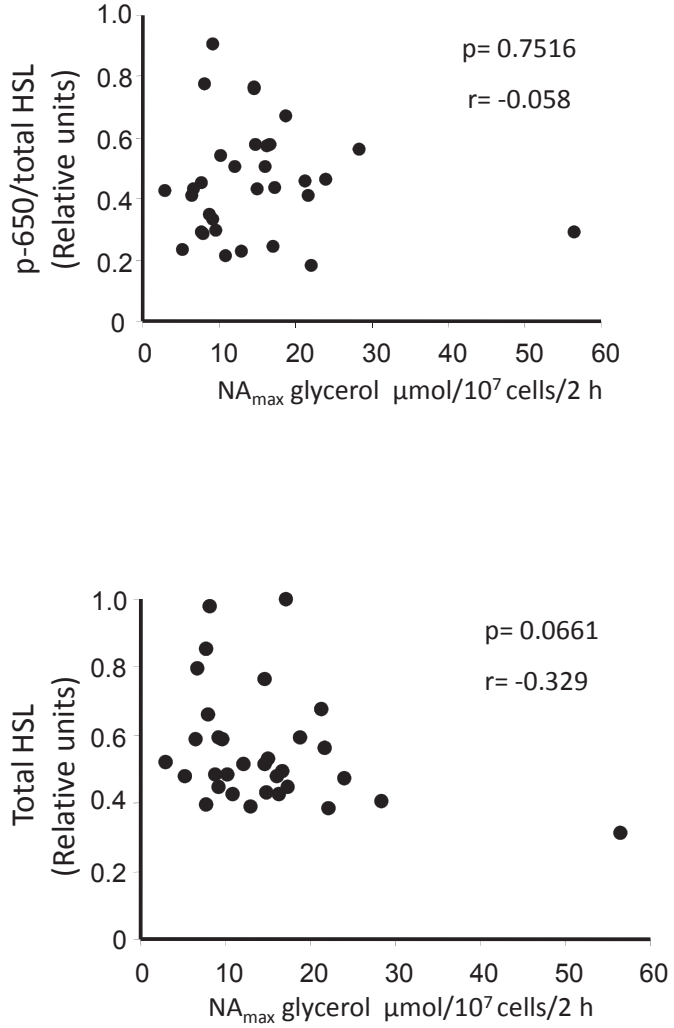

Fig. 4. Correlations between dcAMPstimulated lipolysis and phosphorylated/ total HSL levels. Graphs depicting the correlation between dcAMP $_{\max }$-stimulated lipolysis in vitro and a $\mathrm{p}-\mathrm{Ser}^{552}, \mathbf{b} \mathrm{p}-\mathrm{Ser}^{650}$ and $\mathbf{c}$ - $-\mathrm{Ser}^{554} \mathrm{HSL}$ as well as $\mathbf{d}$ total protein levels $(\mathrm{n}=31)$. The quotient between phosphorylated and total HSL levels was used in a-c. Stimulated lipolysis was assessed by measuring the total amount of glycerol released ( $\mu \mathrm{mol})$ per $10^{7}$ cells after incubation with increasing concentrations of the phosphodiesterase-resistant cAMP-analogue dcAMP for $2 \mathrm{~h}$. dcAMP $_{\text {max }}$ was deter-

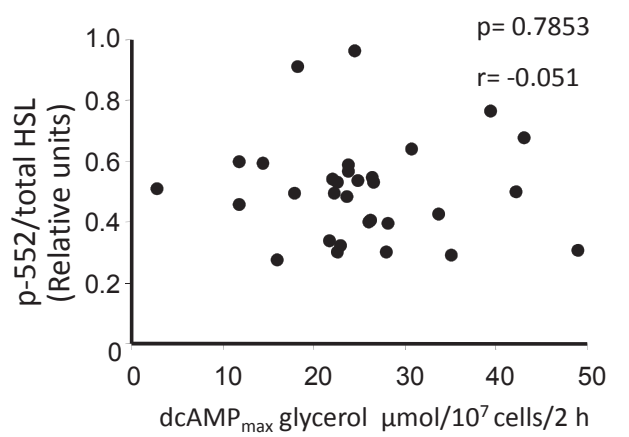

C

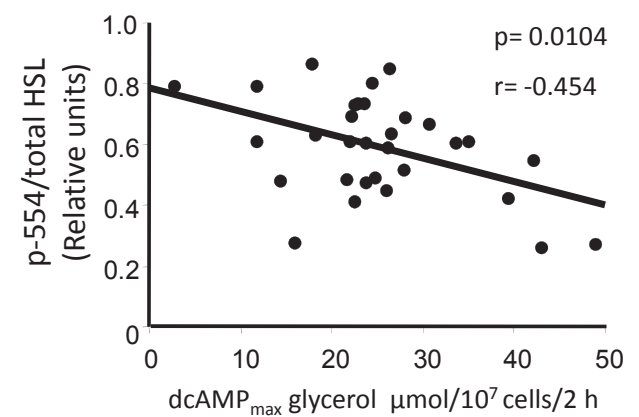

b

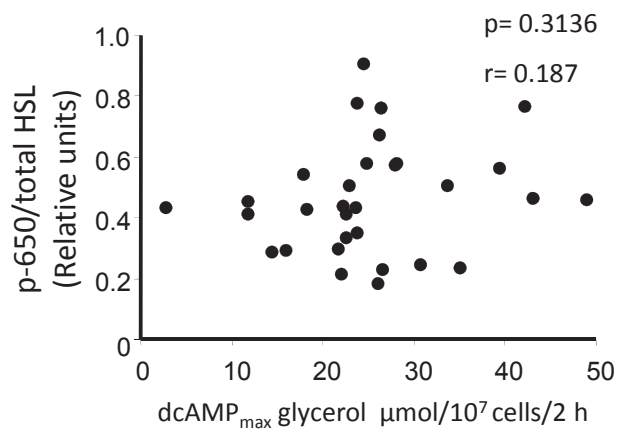

d

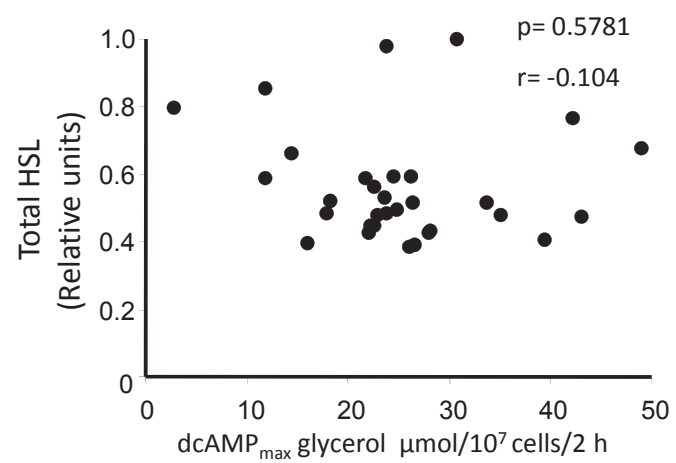

mined as glycerol released at the maximum effective concentration of dcAMP. Correlations were significant also when subtracting basal lipolysis from the dcAMP-stimulated values. 
Table 2. Correlations between p-HSL (Ser552, Ser554, Ser650), total HSL and ATGL with clinical parameters of insulin resistancea

\begin{tabular}{|c|c|c|c|c|c|c|c|c|c|c|}
\hline & \multicolumn{2}{|l|}{$\mathrm{p}-\mathrm{Ser}^{552}$} & \multicolumn{2}{|l|}{$\mathrm{p}-\mathrm{Ser}^{554}$} & \multicolumn{2}{|l|}{$\mathrm{p}-\mathrm{Ser}^{650}$} & \multicolumn{2}{|c|}{ Total HSL } & \multicolumn{2}{|c|}{ Total ATGL } \\
\hline & $\mathrm{p}$ & $\mathrm{r}$ & $\mathrm{p}$ & $\mathrm{r}$ & $\mathrm{p}$ & $\mathrm{r}$ & $\mathrm{p}$ & $\mathrm{r}$ & $\mathrm{p}$ & $\mathrm{r}$ \\
\hline BMI, $\mathrm{kg} / \mathrm{m}^{2}$ & $\begin{array}{l}0.9625 \\
(\mathrm{n}=34)\end{array}$ & -0.008 & $\begin{array}{l}0.7811 \\
(\mathrm{n}=34)\end{array}$ & -0.049 & $\begin{array}{l}0.7597 \\
(\mathrm{n}=32)\end{array}$ & 0.056 & $\begin{array}{l}0.9243 \\
(\mathrm{n}=34)\end{array}$ & 0.017 & $\begin{array}{l}0.8829 \\
(\mathrm{n}=32)\end{array}$ & 0.027 \\
\hline Waist/hip ratio & $\begin{array}{l}0.9743 \\
(\mathrm{n}=34)\end{array}$ & 0.006 & $\begin{array}{l}0.3837 \\
(\mathrm{n}=34)\end{array}$ & -0.154 & $\begin{array}{l}0.5588 \\
(\mathrm{n}=32)\end{array}$ & 0.107 & $\begin{array}{l}0.7496 \\
(\mathrm{n}=34)\end{array}$ & -0.057 & $\begin{array}{l}0.9948 \\
(\mathrm{n}=32)\end{array}$ & 0.001 \\
\hline Insulin, $\mu \mathrm{U} / \mathrm{ml}$ & $\begin{array}{l}0.2256 \\
(\mathrm{n}=28)\end{array}$ & -0.237 & $\begin{array}{l}0.1398 \\
(\mathrm{n}=28)\end{array}$ & -0.286 & $\begin{array}{l}0.5723 \\
(\mathrm{n}=27)\end{array}$ & -0.114 & $\begin{array}{l}0.8234 \\
(\mathrm{n}=28)\end{array}$ & -0.044 & $\begin{array}{l}0.3657 \\
(\mathrm{n}=27)\end{array}$ & 0.181 \\
\hline HOMA index & $\begin{array}{l}0.6651 \\
(\mathrm{n}=25)\end{array}$ & -0.091 & $\begin{array}{l}0.6368 \\
(\mathrm{n}=25)\end{array}$ & -0.099 & $\begin{array}{l}0.5666 \\
(\mathrm{n}=24)\end{array}$ & 0.123 & $\begin{array}{l}0.9359 \\
(\mathrm{n}=25)\end{array}$ & 0.017 & $\begin{array}{l}0.2251 \\
(\mathrm{n}=24)\end{array}$ & 0.257 \\
\hline $\mathrm{TG}, \mathrm{mmol} / \mathrm{l}$ & $\begin{array}{l}0.9216 \\
(\mathrm{n}=33)\end{array}$ & 0.018 & $\begin{array}{l}0.6294 \\
(\mathrm{n}=33)\end{array}$ & -0.087 & $\begin{array}{l}0.8051 \\
(\mathrm{n}=32)\end{array}$ & 0.045 & $\begin{array}{l}0.9646 \\
(n=33)\end{array}$ & 0.008 & $\begin{array}{l}0.9640 \\
(\mathrm{n}=32)\end{array}$ & -0.008 \\
\hline $\mathrm{FFA}, \mathrm{mmol} / \mathrm{l}$ & $\begin{array}{l}0.7934 \\
(\mathrm{n}=26)\end{array}$ & 0.054 & $\begin{array}{l}0.2436 \\
(\mathrm{n}=26)\end{array}$ & -0.237 & $\begin{array}{l}0.9776 \\
(\mathrm{n}=25)\end{array}$ & 0.006 & $\begin{array}{l}0.8206 \\
(\mathrm{n}=26)\end{array}$ & 0.047 & $\begin{array}{l}0.8291 \\
(\mathrm{n}=25)\end{array}$ & 0.045 \\
\hline
\end{tabular}

${ }^{\mathrm{a}}$ Values are mean $\pm \mathrm{SD}, \mathrm{p}$ and $\mathrm{r}$ values are indicated. No statistically significant correlations were found in this cohort $(\mathrm{n}=34)$.

trast, there was no significant association between glycerol release and the degree of phosphorylation at $\operatorname{Ser}^{650}$ and $\operatorname{Ser}^{554}$ (fig. $2 \mathrm{~b}$ and c, respectively). Moreover, in this cohort of obese subjects, there was no correlation between basal lipolysis and total protein levels of HSL (fig 2d) or ATGL ( $r=0.247, p=$ 0.1734 , values not shown). Lipolysis data are here presented per cell but similar significant correlations were also found if glycerol levels were expressed per triglyceride content (graphs not shown). Taken together, these results suggest that phosphorylation at $\mathrm{Ser}^{552}$ is important for the in-between subject variation in basal lipolysis among obese women.

\section{HSL P-Ser ${ }^{554}$ Correlates Negatively with Stimulated Lipolysis in vitro}

HSL phosphorylation levels were next correlated with indices of stimulated lipolysis. Somewhat in contrast to the findings with basal lipolysis, there was no association between P-Ser ${ }^{552}$ or P-Ser ${ }^{650}$ and NA-stimulated glycerol release (fig. 3a or b, respectively). However, we observed a negative correlation between P-Ser ${ }^{55}$ and NA-stimulated lipolysis (fig. 3c, p < 0.01) which would be in agreement with the proposed inactivating role of this residue. In human fat cells, NA stimulates lipolysis via activation of the $\beta_{2}$-adrenoceptor. In order to assess whether there could be differences at the post-receptor level, we also compared the HSL phosphorylation levels with lipolysis stimulated with the phosphodiesterase-resistant cyclic AMP analogue dcAMP. Similar to the findings using NA, there was a negative correlation between $\mathrm{P}_{-} \mathrm{Ser}^{554}$ and dcAMP-stimulated lipolysis (fig 4c) but no correlation with P-Ser ${ }^{552}$ and P-Ser ${ }^{650}$ (fig $4 \mathrm{a}$ and b, respectively). Similar negative correlations between $\mathrm{P}-\mathrm{Ser}^{554}$ and stimulated lipolysis were found when basal lipolysis was subtracted from the $\mathrm{NA}_{\max }$ and dcAMP $\mathrm{Aax}_{\text {max }}$ values (i.e net effect, values not shown). However, there was no significant relationship between HSL (phosphorylated or total levels) and stimulated lipolysis when the latter was expressed as a ratio over basal. Again, the levels of neither total HSL (fig. 3d, 4d) nor ATGL (NA ${ }_{\max } \mathrm{r}=-0.138$, $\mathrm{p}=0.4497 ; \mathrm{dc} \mathrm{AMP}_{\max } \mathrm{r}=0.321, \mathrm{p}=0.0782$; data not shown) correlated with any of the assessed measures of stimulated lipolysis. These results suggest that phosphorylation at $\mathrm{Ser}^{554}$ may be important for variations in stimulated lipolysis in fat cells of obese women.

\section{Phosphorylated HSL, Total HSL, and ATGL Levels Do Not} Correlate with Clinical Parameters of Insulin Resistance

We also determined whether HSL phosphorylation levels as well as total HSL and ATGL levels were correlated with selected anthropometric (BMI and waist/hip ratio) and biochemical measures of insulin resistance (circulating insulin, triglycerides, free FA and HOMA index). However, there was no significant association between the protein levels and any of these parameters (table 2). These findings suggest a more complex relationship between adipocyte lipolysis, adipose lipase protein levels and clinical measures of insulin resistance in obese subjects.

\section{Discussion}

The influence of HSL phosphorylation status on human lipolysis has so far been poorly understood. In the present study, we investigated whether post-translational modifications of HSL in adipose tissue correlated with lipolysis in vitro. We observed that HSL phosphorylation at $\mathrm{Ser}^{554}$ was negatively correlated with NA and dcAMP-stimulated lipolysis which fits with its proposed role as an inactivating phosphorylation site $[15,19]$. In contrast and somewhat surprisingly, we found a negative correlation between HSL phosphorylation at P-Ser ${ }^{552}$ and basal lipolysis. It should be emphasized that it is not clear whether HSL phosphorylation at any serine residue 
has an impact on basal lipolysis since phosphorylation of HSL has so far only been linked to stimulated lipolysis. Moreover, as mentioned previously, the relevance of P-Ser ${ }^{552}$ affecting the enzymatic activity of HSL is not clear $[15,19]$. Nevertheless, our results suggest a potential role for $\mathrm{P}-\mathrm{Ser}^{552}$ in the regulation of basal lipolysis in fat cells from obese women which has not been described before. It could be speculated that increased P-Ser ${ }^{552}$ levels constitute a compensatory mechanism within adipocytes in an attempt to prevent further increase in basal lipolysis in obesity. Admittedly, this hypothesis is only based on descriptive correlations. Unfortunately, it is not possible in human fat cells to selectively phosphorylate the different serine residues in HSL in order to define their individual roles in regulating lipolysis.

Although the negative correlation between stimulated lipolysis and $\mathrm{P}-\mathrm{Ser}^{554}$ is in agreement with previously published data $[15,19]$ and may explain, at least in part, the impairment of catecholamine-stimulated lipolysis in obese subjects $[5,12]$, the mechanisms promoting $\mathrm{P}-\mathrm{Ser}^{554}$ in obesity are largely unknown and should be further characterized. However, it seems plausible that these pathways might involve mechanisms below the level of adenylate cyclase and cAMP production since the same negative correlations were observed after incubation with either NA or dcAMP.

Interestingly, we did not observe any association between HSL phosphorylation levels at $\operatorname{Ser}^{650}$ and measures of basal or stimulated lipolysis. This does not exclude the possibility that phosphorylation at this site may play other roles in the regulation of critical steps of lipolysis such as translocation to the lipid droplet [16], protein-protein interactions with other mediators of lipolysis (e.g perilipin) $[29,30]$ or conformational changes that may facilitate HSL activation. However, further studies are needed to better clarify the functional relevance of HSL-activating phosphorylation sites on stimulated lipolysis in human adipocytes.

Together with $\mathrm{Ser}^{650}, \mathrm{Ser}^{649}$ is considered to be a major determinant of PKA-mediated activation of HSL in humans [23] while $\operatorname{Ser}^{589}$ is phosphorylated by ERKs, but not by PKA. Unfortunately, it was not possible to evaluate the role of either $\mathrm{P}-\mathrm{Ser}^{649}$ or P-Ser ${ }^{589}$ in the present study since there are no commercially available antibodies directed towards these residues. Moreover, it has been suggested that $\mathrm{P}-\mathrm{Ser}^{649}$ is not within an optimal PKA consensus site and is probably phosphorylated at a lower rate than $\mathrm{P}_{-} \operatorname{Ser}^{650}[15,23]$. Therefore, at present, the relevance of $\mathrm{P}-\mathrm{Ser}^{649}$ and $\mathrm{P}-\mathrm{Ser}^{589}$ in human lipolysis remains elusive.

The fact that total HSL and ATGL protein levels were not correlated with basal or stimulated lipolysis is notably relevant. Though we previously reported that the amount of HSL and ATGL protein was decreased in fat cells and adipose tissue from obese subjects [5, 31], it appears that their levels do not predict lipolytic capacity (basal or stimulated lipolysis) in human fat cells, at least in the cohort of obese subjects analyzed in this study. This suggests that HSL phosphorylation, rather than total HSL or ATGL protein content, is primarily involved in the regulation of lipolysis in human fat cells of obese individuals.

There is no consensus regarding how to express stimulated lipolysis (e.g per lipid weight of incubated sample, per fat cell number, per fat cell protein content, per DNA of fat cells, as net effect over basal or as the ratio over basal). Our findings were similar when stimulated lipolysis was expressed both as absolute values (corrected for lipid weight or fat cell number) and as the net effect, but not when expressed as the ratio over basal. The reason for this is not clear at the moment. However, it is possible that lipolysis expressed as the ratio over basal may be more correct when comparing lean with obese cohorts since these groups display large differences in fat cell size and thereby basal lipolysis rates.

A caveat in the present study is that we only used adipose tissue from women. Thus, we cannot exclude the possibility that gender differences could have an impact on the results since adipocyte lipolysis is differentially regulated in men and women [reviewed in 3, 32]. Moreover, the relationship between HSL phosphorylation levels and fat cell lipolysis in lean subjects remains to be determined. Unfortunately, the amount of adipose tissue that can be obtained from lean subjects in clinical settings like ours is too small for this type of study.

In conclusion, our results suggest that post-translational modifications of HSL impact on lipolysis. While P-Ser ${ }^{554}$ and P-Ser ${ }^{552}$ predict lipolytic activity of adipocytes in vitro, neither P-Ser ${ }^{650}$ nor total HSL protein levels were associated with differences in lipolysis. Although part of our results are in agree-

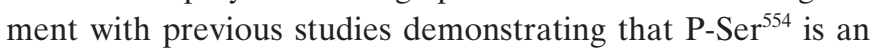
inactivating site, our present data also suggest a regulatory role for $\mathrm{Ser}^{552}$ in basal lipolysis. Further mechanistic studies will be needed in order to define the pathophysiological role of these residues in human adipose tissue.

\section{Acknowledgements}

We are very grateful to Kerstin Wåhlén, Eva Sjölin and Elisabeth Dunger for excellent technical assistance. This work has been supported by 'Adipokines as Drug Targets to Combat Adverse Effects of Excess Adipose Tissue' ADAPT (nr 201100), COST BM0602, The Swedish Research Council, The Swedish Diabetes Association, the Novonordisk Foundation and the Diabetes Theme Center at the Karolinska Institute. Finally, we also acknowledge all the volunteers who participated in the study. All the authors have read and approved submission of the manuscript.

\section{Disclosure Statement}

The authors declare no conflicts of interest. 


\section{References}

1 Dandona P, Aljada A, Chaudhuri A, Mohanty P, Garg R: Metabolic syndrome: a comprehensive perspective based on interactions between obesity, diabetes, and inflammation. Circulation 2005;111: 1448-1454.

2 Enoksson S, Talbot M, Rife F, Tamborlane WV, Sherwin RS, Caprio S: Impaired in vivo stimulation of lipolysis in adipose tissue by selective beta2adrenergic agonist in obese adolescent girls. Diabetes 2000;49:2149-2153.

3 Arner P: Human fat cell lipolysis: biochemistry, regulation and clinical role. Best Pract Res Clin Endocrinol Metab 2005;19:471-482.

4 Lofgren P, Hoffstedt J, Naslund E, Wiren M, Arner P: Prospective and controlled studies of the actions of insulin and catecholamine in fat cells of obese women following weight reduction. Diabetologia 2005;48:2334-2342.

5 Large V, Reynisdottir S, Langin D, Fredby K, Klannemark M, Holm C, Arner P: Decreased expression and function of adipocyte hormone-sensitive lipase in subcutaneous fat cells of obese subjects. J Lipid Res 1999;40:2059-2066.

6 Horowitz JF, Coppack SW, Paramore D, Cryer PE, Zhao G, Klein S: Effect of short-term fasting on lipid kinetics in lean and obese women. Am J Physiol 1999;276:E278-284.

7 Arner P: Insulin resistance in type 2 diabetes: role of fatty acids. Diabetes Metab Res Rev 2002;18 (suppl 2):S5-9.

8 Lafontan M, Langin D: Lipolysis and lipid mobilization in human adipose tissue. Prog Lipid Res 2009;48:275-297.

- Watt MJ, Steinberg GR: Regulation and function of triacylglycerol lipases in cellular metabolism. Biochem J 2008;414:313-325.

10 Jocken JW, Langin D, Smit E, Saris WH, Valle C, Hul GB, Holm C, Arner P, Blaak EE: Adipose triglyceride lipase and hormone-sensitive lipase protein expression is decreased in the obese insulin-resistant state. J Clin Endocrinol Metab 2007; 92:2292-2299.

11 Mairal A, Langin D, Arner P, Hoffstedt J: Human adipose triglyceride lipase (PNPLA2) is not regulated by obesity and exhibits low in vitro triglyceride hydrolase activity. Diabetologia 2006;49:1629_ 1636.

12 Mottagui-Tabar S, Ryden M, Lofgren P, Faulds G Hoffstedt J, Brookes AJ, Andersson I, Arner P: Evidence for an important role of perilipin in the regulation of human adipocyte lipolysis. Diabetologia 2003;46:789-797.
Agustsson T, Ryden M, Hoffstedt J, van Harmelen V, Dicker A, Laurencikiene J, Isaksson B, Permert J, Arner P: Mechanism of increased lipolysis in cancer cachexia. Cancer Res 2007;67:5531-5537.

14 Lass A, Zimmermann R, Haemmerle G, Riederer M, Schoiswohl G, Schweiger M, Kienesberger P, Strauss JG, Gorkiewicz G, Zechner R: Adipose triglyceride lipase-mediated lipolysis of cellular fat stores is activated by CGI-58 and defective in Chanarin-Dorfman syndrome. Cell Metab 2006;3: 309-319.

15 Anthonsen MW, Ronnstrand L, Wernstedt C, Degerman E, Holm C: Identification of novel phosphorylation sites in hormone-sensitive lipase that are phosphorylated in response to isoproterenol and govern activation properties in vitro. $\mathrm{J} \mathrm{Biol}$ Chem 1998;273:215-221.

16 Su CL, Sztalryd C, Contreras JA, Holm C, Kimmel AR, Londos C: Mutational analysis of the hormone-sensitive lipase translocation reaction in adipocytes. J Biol Chem 2003;278:43615-43619.

17 Greenberg AS, Shen WJ, Muliro K, Patel S, Souza SC, Roth RA, Kraemer FB: Stimulation of lipolysis and hormone-sensitive lipase via the extracellular signal-regulated kinase pathway. J Biol Chem 2001; 276:45456-45461.

18 Daval M, Diot-Dupuy F, Bazin R, Hainault I, Viollet B, Vaulont S, Hajduch E, Ferre P, Foufelle F: Anti-lipolytic action of amp-activated protein kinase in rodent adipocytes. J Biol Chem 2005;280: 25250-25257.

19 Garton AJ, Campbell DG, Carling D, Hardie DG, Colbran RJ, Yeaman SJ: Phosphorylation of bovine hormone-sensitive lipase by the AMP-activated protein kinase. A possible antilipolytic mechanism. Eur J Biochem 1989;179:249-254.

20 Sullivan JE, Brocklehurst KJ, Marley AE, Carey F, Carling D, Beri RK: Inhibition of lipolysis and lipogenesis in isolated rat adipocytes with AICAR, a cell-permeable activator of AMP-activated protein kinase. FEBS Lett 1994;353:33-36.

21 Yin W, Mu J, Birnbaum MJ: Role of AMP-activated protein kinase in cyclic AMP-dependent lipolysis in 3T3-L1 adipocytes. J Biol Chem 2003; 278:43074-43080.

22 Gaidhu MP, Fediuc S, Anthony NM, So M, Mirpourian M, Perry RL, Ceddia RB: Prolonged AICAR-induced AMP-kinase activation promotes energy dissipation in white adipocytes: novel mechanisms integrating HSL and ATGL. J Lipid Res 2009:50:704-715.
3 Krintel C, Osmark P, Larsen MR, Resjo S, Logan DT, Holm C: Ser649 and Ser650 are the major determinants of protein kinase A-mediated activation of human hormone-sensitive lipase against lipid substrates. PLoS One 2008:3:e3756.

24 Watt MJ, Holmes AG, Pinnamaneni SK, Garnham AP, Steinberg GR, Kemp BE, Febbraio MA: Regulation of HSL serine phosphorylation in skeletal muscle and adipose tissue. Am J Physiol Endocrinol Metab 2006;290:E500-508.

25 Wahrenberg H, Hertel K, Leijonhufvud BM, Persson LG, Toft E, Arner P: Use of waist circumference to predict insulin resistance: retrospective study. BMJ 2005;330:1363-1364.

26 Lofgren P, Hoffstedt J, Ryden M, Thorne A, Holm C, Wahrenberg H, Arner P: Major gender differences in the lipolytic capacity of abdominal subcutaneous fat cells in obesity observed before and after long-term weight reduction. J Clin Endocrinol Metab 2002;87:764-771.

27 Aboulaich N, Chui PC, Asara JM, Flier JS, Maratos-Flier E: Polymerase I and transcript release factor regulates lipolysis via a phosphorylation-dependent mechanism. Diabetes 2011;60:757-765.

28 Stenson BM, Ryden M, Venteclef N, Dahlman I, Pettersson AM, Mairal A, Astrom G, Blomqvist L, Wang V, Jocken JW, Clement K, Langin D, Arner $\mathrm{P}$, Laurencikiene J: Liver X receptor (LXR) regulates human adipocyte lipolysis. J Biol Chem;286: 370-379.

29 Granneman JG, Moore HP, Granneman RL, Greenberg AS, Obin MS, Zhu Z: Analysis of lipolytic protein trafficking and interactions in adipocytes. J Biol Chem 2007;282:5726-5735.

30 Wang H, Hu L, Dalen K, Dorward H, Marcinkiewicz A, Russell D, Gong D, Londos C, Yamaguchi T, Holm C, Rizzo MA, Brasaemle D, Sztalryd C: Activation of hormone-sensitive lipase requires two steps, protein phosphorylation and binding to the PAT-1 domain of lipid droplet coat proteins. J Biol Chem 2009;284:32116-32125.

31 Jocken JW, Goossens GH, van Hees AM, Frayn KN, van Baak M, Stegen J, Pakbiers MT, Saris WH, Blaak EE: Effect of beta-adrenergic stimulation on whole-body and abdominal subcutaneous adipose tissue lipolysis in lean and obese men. Diabetologia 2008;51:320-327.

32 Blaak E: Gender differences in fat metabolism. Curr Opin Clin Nutr Metab Care 2001;4:499-502. 